\title{
1. Introduction: two different Western models
}

This book contrasts two different approaches to each of the three topics discussed: the rule of law, economic development, and corporate governance. The aim is not to add to what is already an over-politicized view of the world; nor is it an effort to prove that one view is better than another, as each presents both advantages and disadvantages. It is instead an effort to show that there is a different way to see and understand the ongoing dichotomy between two views - one that avoids politicization, moral posturing, resentment, and virtue signaling; and is more concerned with enabling various cultures to use inductive knowledge of themselves, their strengths, and their weaknesses to effectuate positive changes in any or all of the three areas.

Rather than a Tale of Two Cities (with apologies to Charles Dickens), this is a tale of two views of the relationship among human beings, the rule of law, economic development, and corporate governance.

\section{THE BOOK AND ITS APPROACH}

The rule of law bakes no bread, it is unable to distribute loaves or fishes (it has none), and it cannot protect itself against external assault; but it remains the most civilized and least burdensome conception of a state yet to be devised.

The rule of law is widely recognized as necessary for a stable society, and is generally accepted as related to economic development; but neither the history and development of the rule of law nor its relationship to economic development has been carefully explored. Furthermore, although a number of multinational entities - such as the United Nations, the World Bank, and the World Justice Project - recognize the importance of the rule of law, their underlying premise that there is only one understanding of the concept is belied by recent developments in two common law jurisdictions: England and Hong Kong. Economic development is generated by the success of businesses large and small, and that success depends (in part) on whether they are properly governed. Scandals have rocked or destroyed some of the largest businesses in the world, and so far no set of laws has been able to prevent such scandals. This book presents a contextual and careful study of three human constructs 
and the relationship among them: the rule of law, economic development, and corporate governance.

As of this writing, Hong Kong is experiencing large-scale, ongoing protests against intrusions by mainland China that challenge and undercut Hong Kong's common law system in contravention of the "one country, two systems" promise of 1997. Furthermore, Boris Johnson's recent success in England's general election is a reaffirmation of England's popular vote to leave the European Union. As confirmed by Brexit exit polls, philosopher Roger Scruton correctly anticipated that the English would want to leave for two reasons:月 (1) the E.U. top-down legal system violates the traditional British understanding of the relationship between citizen and government (49 percent), and (2) E.U. membership and the requisite acceptance of its directives were seen as a cause of economic problems caused by large numbers of immigrants ( $\sim 33$ percent). . Hong Kong is recognized worldwide for its economic freedom and its rule of law. The legal changes demanded or requested by mainland China (approval power over Hong Kong's top executive and expropriation of those suspected of crimes by the mainland) jeopardize both economic freedom, and what remains of political freedom and the common law tradition of self-government.

The underlying prevailing assumption is that only one Western conception of the rule of law exists, and that it encompasses both common law and civil law governments. This is belied not only by recent events in Hong Kong and England, but also by the history, cultures, and scholarship of both types of legal systems. In truth, two distinct and separate conceptions underlie the two legal systems: the Anglo-American rule of law and the continental (or civilian) rule through law or rechtsstaat. That same body of history and scholarly tradition, when studied, shows two different conceptions of the relationship between the rule of/through law and economic development. Furthermore, economic development is brought about by corporations, large and small, that produce profit-making products and services, and which are themselves created by law. Here, too, there exist two different legal conceptions of the proper nature of a corporation and the proper approach to corporate problems such as corruption and malfeasance.

This book begins with a study of the development and meaning of the two different conceptions: rule of law and rule through law. That study is in historical context because it is historical explanations of how social institutions develop that make the most sense, as opposed to out-of-context scientistic explanations ("scientistic" referring to explanations that purport to use the deductive methodology of experimental science to explain social institutions). History is a unique mode for understanding human conduct that cannot be reduced or replaced by science or social science. It allows one to see cause and effect and inter-relationships that other approaches do not. The book then does 
the same with economic development and finishes by discussing corporate problems in both Germany and the United States and the two different conceptions of corporate governance - stakeholder and shareholder theory-how they relate to the rule of law and economic development, and what approach is best in addressing what are likely recurrent problems of corporate behavior.

This chapter will first explain the order of presentation, then some of the underlying concepts with which the reader may be unfamiliar, and finally an explanation of what the author hopes will be the utility of this new approach to the topic: a time-tested approach that various cultures and jurisdictions can use to implement constructive, effective legal change rather than ineffective and possibly even destructive adoption of legal transplants.

\section{ORDER OF PRESENTATION}

Chapter 2 explains the English rule of law and its development since "Time Immemorial" - that is, from before the Norman Conquest until the twentieth century. The rule of law may be described as not just a habit of law and order, but also a conception of the power of government as limited, such that the people have the underlying right to be left alone, and government may intrude only when necessary to protect peace. It protects individual freedom, based on equality before the law. The English habit of limited government and its valuing individualism developed organically. Limited government was apparent as early on as the first century A.D. and developed further after the Norman Conquest through kings such as Henry II, who founded England's common law and the jury trial, and began the secularization and centralization of law and focus on empiricism. Individualism was present as early as the thirteenth century, as shown in Alan MacFarlane's studies of property and inheritance habits. The tradition of imposing limits on government continued, as shown in constitutional documents such as the Magna Carta, which listed all-ready customary limitations on governmental power; the English "disease" of dethroning (and even murdering) tyrannical monarchs; and actions by both Parliament and such luminaries as Edward Coke, who limited not just the king's prerogative and his taxing powers, but also governmental power in general. In the nineteenth and twentieth centuries, legal scholars Dicey, Hayek, Oakeshott, Fuller, and Leoni described both the tradition and the modern danger it is facing from the bureaucratic state.

Chapter 3 discusses the development of the civil law concept, the rule through law, otherwise known as rechtsstaat. Rechtsstaat similarly values a habit of law and order; but rather than limiting governmental power, it posits that the state must adhere to its own laws, and that law is developed and imposed from the top down by experts. Rechtsstaat is predicated on Rousseau's general will and collectivism, rather than individualism. Though human rights 
are regarded as important, they are defined by the state, and come with duties toward the state. Rechtsstaat was re-invigorated after the Second World War, such that Germany, for example, sees the state's purpose and duty as being to protect and develop human dignity. Civilian rights are positive in nature and often listed. Like Chapter 2, this chapter traces the development of rechtsstaat from the fall of ancient Rome to the modern age, showing how it grew out of reactions to problems created by feudalism, war, religious intolerance, and the substitution of legislative supremacy and collectivism for absolute monarchy.

Chapter 4 describes how the rule of law grew and changed in the United States. The American founders thought they were adopting their common law heritage; but their habit of hustle, wide experience with various popular governments, and exposure to the Scottish Enlightenment led them ultimately to develop a compound and commercial republic. The American conception of the rule of law was grounded in self-criticism and a skeptical view of "paper" limits on governmental power. It self-consciously imposed a complicated system of checks and balances in order to help protect the rule of law and limited government. The American understanding of equality under the law was severely tested by the anachronism of the presence of slavery at the founding, the Civil War necessarily born out of the divisions between slave-holding and free states, and the legacy of the Jim Crow era. The country still struggles to live up to the ideals presented in its Declaration of Independence after the 1960s civil rights era.

Chapter 5 shows how the conflict between the rule of law and rechtsstaat has developed in the last century-and-a-half in the United States, beginning with the progressivist movement and legal realists who wrestled with the problems brought by the country's rapid urbanization and industrialization in the golden age. Some legal scholars have confused rechtsstaat with the rule of law, or even dismissed the rule of law altogether. Scholars such as Hart, Rawls, Dworkin, and Unger all focus on equality and collectivism, minimizing the value of liberty, and oddly ignoring in large part the very existence of any other developed viewpoint. Other very prominent scholars who find the rule of law more valuable than ever in protecting both liberty and economic development include Fuller, Hayek, Oakeshott, and Zywicki, among others.

Chapter 6 moves to a discussion of economic development. Like Chapters 2-4, it begins with a short comparative history of Western economic development from feudalism to mercantilism to market economics, tying it in with the growth and development of the rule of law/rechtsstaat. It then moves on to the United States. While the United States began with mercantilism, both the founders and the public were influenced by England's expansion into a commercial powerhouse and economic studies such as Adam Smith's Wealth of Nations. Alexander Hamilton helped turn the northern part of the country into a commercial republic, while the South's slavery-based feudalistic economy 
led inexorably to economic disaster. A discussion follows of how the problems brought by the post-Civil War's heavy industrialization, urbanization, and the Great Depression, combined with economic theory ranging from Keynes to Friedman, fed into the modern conflict between free market/rule of law and economic engineering/rechtsstaat.

Chapter 7 discusses economic growth, the various indexes of economic development and entrepreneurship, and why and how it is that those countries that share a rule of law heritage remain disproportionately at the top, as studied by economist Svetozar Pejovich. Economic growth is fueled by the presence of either the rule of law or rechtsstaat, but it also needs a culture that encourages entrepreneurship in order to be lasting and lead to widespread improvement in quality of life. Economists Hayek and de Soto have found that common law dominance can be attributed in part to the ease of registering property and businesses (de Soto), as well as the trust in the spontaneous order of the market and the comparative lack of bureaucratic regulation (Hayek). While China has experienced massive economic development, it is struggling to enable innovation - probably due in part to the fact that it increasingly limits the freedom of its citizens through surveillance, and increasingly limits their access to the internet and the outside world, both of which are unlikely to enable innovation and thus likely to slow down development. The bureaucratic state, a danger everywhere, poses a drag on economic development and interferes with the rule of law. While income disparity is touted as a cause necessitating the regulatory state, this chapter explains why it is a non-issue in a growing economy. In contrast, the encouragement of small businesses, with their tendency to bring innovation and enabling their ability to obtain capital needed to grow, is of marked importance.

Chapter 8 describes the two primary views of corporate governance: shareholder theory and stakeholder theory. Shareholder theory developed from U.S. case law and is consistent with the common law conception of law. Stakeholder theory is consistent with civil law and has been mandated by legislation in the E.U. and elsewhere. Common law corporate structure has resulted in the democratization of ownership, wherein a wide spectrum of society invests in, and thus provides capital for, corporate development. Corporate ownership in civil law jurisdictions is much narrower and often involves interlocking directorates or partial governmental ownership, wherein the focus of the directors is more on maintaining jobs than maintaining or increasing profitability.

Regardless of which legal system applies, however, corporate problems such as fraud, bribery, and crony capitalism afflict companies in both common law and civilian jurisdictions. For this reason, after discussing recent corporate scandals in both Germany and the United States, and some of the measures implemented in reaction to them, the chapter concludes that in order to maintain the goals of liberty, entrepreneurship, and economic freedom, corporate 
governance should be as free from legislation and regulation as possible, with the law stepping in only when there is evidence of fraud or malfeasance. Contrary to contemporary theories about using regulation, stakeholder theory, and enhanced reporting requirements to prevent corporate malfeasance, it is best for both the rule of law and economic freedom to encourage "soft law," and let the market punish corporate inefficiency, ineffectiveness, and amoral acts short of criminal behavior. People in big business (and lawyers) often have an exaggerated understanding of what law can and cannot do. Law cannot stop people from doing bad; it cannot force them to do good; it can only deter, punish, and reward.

\section{THE IMPORTANCE OF SPONTANEOUS ORDER}

Hayek posited that most human institutions grow spontaneously. Spontaneous institutions such as language develop a certain order that improves functionality through custom and experience. With regard to economics, he argued that the extended or spontaneous order of a market economy provides a more efficient allocation of societal resources than any design could achieve and is superior to any order that a human mind could design because the human mind cannot by itself aggregate the necessary data. In a market economy, price is the aggregation of information acquired by individuals, thus allowing those dealing in a commodity to make decisions based on more information than they could acquire personally or from any centralized authority. This is especially true in the age of the internet! Thus, the market economy's inherent efficiency benefits the whole society.

Spontaneous order develops out of the fact that human action precedes human thought, and practice precedes theory. Individuals pursuing individual goals in exchanging with each other do not intend to create any kind of order through a previously agreed-upon plan. They may not even speak a common language, but still find ways to carry out cooperative undertakings. After succeeding at their exchange, they are then likely to articulate their understanding and lay the groundwork for future undertakings. They are unlikely even to articulate any rules for their exchanges until someone fails to perform or some disagreement arises on the next step. People begin to gather at a specific place in order to exchange goods; they develop habits of ascertaining prices - perhaps by shouting out competing offers from among a crowd, as on the New York Stock Exchange floor or at an auction. They bring similar goods to a common place, so as to attract both more merchants and more customers, who then collect information for themselves on who has the best farm-fresh tomatoes, or who offers the lowest prices. Slowly, out of an accumulation of such exchanges, a social order emerges. 
The glue that holds society together, that makes communication possible and protects against constant breakdown, is the grounding in social practice. Cultures are not rigid structures whose essence can be captured like a photograph and which never change or evolve. They cannot be reduced to a deductively organized set of principles or described by referring to a hidden structure, as in physics (molecules and atoms) or biology (cells). No culture is barred from moving in a new direction (good or bad), as long as some inherited practice can be interpreted to explain or justify what originally might appear to be alien.

The rule of law-meaning the supremacy of the law, its equal application, and its being subject to review by independent courts and its imposition of limits on governmental power, and even the due process rights of the Magna Carta and other of England's constitutional documents - evolved out of the spontaneous order and traditions of the Anglo-American judicially created legal inheritance. Such judicially made law, because it is justified on what came before and then interpreted and re-interpreted, is an open-ended practice. Thus, unbiased adjudication is based on reflection on pre-existing practice and its aims. It requires interpretation, reinterpretation, and application to specific facts, and is subject to revision (even by subsequent legislation). It can continue to evolve through the conscious efforts of its participants, who seek to apply inherited rules to new circumstances. Or who are, in contrast, free to find that the inherited rule is no longer justified because the new circumstances are dissimilar, and that the old rule no longer functions or contradicts a more modern public policy interest and must therefore be adapted to suit new conditions. Because judges must justify their holdings by reference to prior case law (not personal feelings or political agendas), and because their written holdings include these justifications and are then subject to review by higher-level courts, changes are gradual, reached by consensus, and the law remains relatively predictable - contrary to the opinions of some of those not familiar with common law process. Both Friedrich Hayek and Bruno Leoni described the development of common law as an instance of spontaneous order, arguing that such development is an advantage.

In contrast, civil law and civil codes did not develop spontaneously. Hayek argues that constructivist rationalism - by which he means the civilian concept that all law can be logically derived from a priori premises and should be a deliberate construction (i.e. legislated law) — contrasts with the spontaneous legal rules that developed out of judicial habit for which law and liberty cannot exist apart from one another.

Not only Civil Codes, but also legislation and (in particular) legislative supremacy, have disadvantages as compared to judge-made law. As Leoni explains it, legislation is now seen as a panacea-hence the term "legislative supremacy." It seems to be a quick, rational, and far-reaching remedy against 
every kind of evil or inconvenience. A corporation's filings are fraudulent? Pass another Act imposing even stricter punishments than were already in place! People are still using illegal drugs? Pass a law stipulating longer criminal sentences! Neither solution is likely to be effective: people will still use illegal drugs, and corporations in difficult circumstances will still be tempted to lie on their filings. 1 The law cannot prevent bad acts.

In fact, however, legislation may be too quick to be efficacious, too unpredictably far-reaching to be wholly beneficial, and too directly connected with the views and interests of a handful of people (the legislators themselves) to be a remedy for all concerned. As lawyers more commonly describe it, legislation can be over-broad, or too narrow, and can even lead to exactly the opposite result of what the legislators intended Legislation, as such, comes about by means of a majority vote of legislators. By its very nature, it intrudes on individual liberty. It is grounded in the assumption that the legislators who draft it represent their citizens and can be relied on to vote in their interest. Yet, once elected, legislators are expected to collaborate in various committees by doing such things as bending to lobbyist interests, trading votes, and so on. All of this has led to a kind of schizophrenia and fiction that legislators: (1) know what is in their constituents' best interests and what they would want if they were asked; and (2) are likely to act in the same vein. The result has been a massive growth of legislation and regulation, such that individuals are not only prevented from freely deciding what they want to do, but also unable to foresee the legal effects of their daily behavior without advice from a lawyer.

While rationalism and deliberate actions have their place, spontaneous order allows for greater flexibility and often the development of very effective social habits, whether in law, economics, or corporate governance.

\section{CIVIL ASSOCIATIONS, ENTERPRISE ASSOCIATIONS, AND INSTRUMENTALISM}

Part of the dichotomy between the rule of law and rechtsstaat is a difference in understanding of the purpose of government. Michael Oakeshott used the term "enterprise association" to describe any kind of human association held together and driven by a common goal. 1 For example, a business is an enterprise association because its members are focused on the goal of producing a profit-making product or service. A soccer team is an enterprise association because its goal, toward which all team members work, is to win soccer games.

In keeping with their history, as explained in Chapter 3, civil law jurisdictions tend to view government as an enterprise association, whose purpose is to improve the people themselves, their lives, or both. For example, Germany's Basic Law incorporates positive values that obligate governmental authorities to consider fundamental rights such as human dignity at all times and create 
the best conditions possible under the circumstances for their effective enjoyment. Some of these values typically include a right to education, housing, a particular retirement age, a short work week, perhaps a "decent" income, in addition to life, liberty, and the pursuit of happiness. Such values may be difficult both to define and to enforce. They lead to entrenched entitlement programs and the vast and expensive bureaucracies needed to effectuate them - and they create expectations among the polity that the government will provide. Anytime a government passes a law designed to achieve some end-an instrumental law such as one subsidizing "green" technology-it becomes an enterprise association. All governments, at times, are enterprise associations - for example, when at war or when fighting a pandemic such as Covid-19. In any such instance, the government is inevitably limiting freedom.

In contrast to enterprise associations, Oakeshott posits that some human associations are civil in nature, meaning that they are not created with any particular goal or end in mind for any particular group. The only goal in governing, if there is one, is to protect "the king's peace" against intrusion from outside and to discourage or punish bad behavior inside the polity. In such associations, the best laws are non-instrumental or "adverbial" ones. They do not dictate what one should do, but instead direct only how one should do it. For example, in every country there is a law dictating which side of the street one should drive on, and often a speed limit. Such laws do not dictate where you should go - that is left up to the individual — but only how you should do so. The purpose is to maximize the safety and freedom of driving. There may be governmental projects such as bridges and roads designed to benefit all who use them, but a minimum of laws that benefit only a sub-part of the group. American Lon Fuller advocated for civil association, though in different terms: "law furnishes a baseline for self-directed action, not a detailed set of instructions for accomplishing specific objectives."

Government as a civil association, therefore, does not advocate for any particular group or mythical whole; and the individual, therefore, remains with the right to be left free of governmental interference.1 In other words, rights in this view are "negative," inalienable, and precede any governmental power. Individuals have a general right to be free from governmental interference, unless they are intruding on another individual's freedom. These rights are indefeasible, or inalienable, including only "life, liberty, and the pursuit of happiness," and precede any governmental power. In such a system, the need for consensus is maximized and politicization is minimized, as (hopefully) no particular group experiences governmental favor long enough to push through its own enterprise agenda. Because of the habit of equal treatment before the law, individuals develop respect for the law as separate from those people who dominate the government. They expect and demand that the government will obey and apply the law; and they have as a result an implicit belief that not only 
will the law not interfere unduly with their entrepreneurial efforts, but also that they can rely on the law to protect their economic enterprises. This does not mean that "safety net" programs for the poor must be rejected as creating an "enterprise association;" but it does mean that care and consideration should be given in designing such programs so that they are limited in size and scope, and in fact enable the poor to move up and out of poverty rather than trapping them in it.

Both civil and enterprise associations are grounded in ideals that cannot fully be realized, and each culture decides for itself where in the spectrum between the two ideals it wants to be placed. It's better, however, that this be a conscious choice, made with an understanding of likely consequences.

One of the primary advantages of the civil association view of government is that it minimizes politics. In contrast, an enterprise association is invariably politicized. Karl Marx may have been right that politics and class warfare are part of a market economy, but under a civil association such divisiveness can be minimized by emphasizing the need for ground-up consensus in order to effectuate positive changes. Otherwise, each political group merely waits for its time at the top, where it feels free to impose its views and desires on the rest of society. In a modern society that includes very divergent opinions, religions, morals, and needs, regarding government as primarily a civil society focuses on a need for bottom-up, win-win consensus, rather than lose-lose constant political competition. It's the opposite, if you will, of extremists in the critical legal studies movement, who regard all law as the result of a political battle and an unjustified imposition by the haves on the have-nots, and who may hope for the next revolution — not knowing whether or why it might result in a better situation or simply anarchy.

\section{NON-CARTESIAN REASONING}

Common law and civil law attorneys think about law differently due to underlying differences in reasoning. As explained in Chapter 3, civilians began with the premise that legislated law is the only justified source in popular government, because it is created by means of legislative (general) will - the voice of the people. (Leoni argued that view is fictitious.) Furthermore, legislated law should be and can be deduced from first principles, so that it all fits neatly into an Aristotelian/teleological order. The judges' job, therefore, is merely to apply the facts to the law without interpreting the law-something to be avoided, because it would carry the taint of medieval glossators. Hayek, in particular, dislikes scientism (the misuse of hard science as the model for scholarship about social institutions) and blames its development on Descartes.

This, now, is a caricature of the modern civilian viewpoint, as civil law jurisdictions vary widely. All have realized that not all legislated law can be 
fit into the beautiful, coherent deductive order of a civil code; and almost all realize that judges (of necessity) must interpret law. Nevertheless, the original Cartesian view of law as a legal science remains, to varying extents. Even when "jurisprudence" is an accepted source of law, judicial decisions are not nearly as carefully justified or subject to accountability as they are in common law.

Deductive reasoning (the syllogism) is used in all judicial reasoning, both common law and civil law, and is widely regarded as the only kind of "logical" reasoning. It is a very useful tool-it helps a great deal in explaining concepts - but it is not indigenous to all cultures; nor is it the only kind of reasoning available. Inductive reasoning can be similarly helpful, and is used in common law when it re-examines decisions that have been made previously to see what insights can be drawn, as well as when it uses analogy. Common law involves factual comparisons - reasoning by analogy and distinction-as an ultimate arbiter in reasoning through a legal decision.

Consequently, by tradition (and as explained further in Chapter 3), common law judges consider deductive reasoning, inductive reasoning, and the facts of earlier cases in deciding whether a judicially created legal principle applies to a new conflict.

\section{EFFECTIVE AND INEFFECTIVE CHANGE}

The author's background in comparative law makes her all too familiar with the problems inherent in legal transplants. For example, Turkey's 1926 adoption of the entire Swiss Civil Code originally caused a number of problems, including the instant legal dissolution of a number of Islamic marriages and the resulting delegitimizing of the children of those marriages. 17 Turkey's example is, admittedly, extreme; but less encompassing transplants are also unsuccessful where they are not carefully tailored to existing legal culture and practice. Even where a transplant is successful, its implementation is likely to be very different from the original, because of differences in culture, history, and understanding.

Not only are legal transplants likely to be unsuccessful; so too are programs by well-meaning multinational entities. For example, multinational agencies have tried to effectuate legal reform and development in Latin America since the 1960s. 1 These reform efforts in Latin America have been grouped in three bands: (1) the 1960s-70s "law and development" movement, which encouraged countries to adopt a U.S.-style legal system; (2) the 1980s much smaller-scoped "Administration of Justice" program; and (3) the 1990s "rule of law" program. All three were unsuccessful. 19 The first failed because it tried to make broad-scoped change while ignoring and dismissing local culture and civil law heritage. The second failed because its attempt merely to reform the 
justice sector was too narrow, in that it excluded legal education and legislative drafting, as well as being extraordinarily expensive. The third band, which tried to emphasize "rule of law" and independent judiciary, also failed because it also tried to implement change in the target countries without first achieving a consensus and was, again, enormously expensive.

A spectacular example of a failure in the 1990s band of reform efforts is that of Venezuela. The World Bank supplied Venezuela with consultative expertise and considerable funds ( $\$ 35$ million) to reform its judicial system, which had been inefficient, corrupt, lacking in resources, and heavily politicized. In 1998, a new system of justices of the peace was created to serve underserved communities, a new penal code was drafted, and new procedures were implemented, including an adversarial system, district attorneys, oral procedures, open trials, and even plea bargaining. The very next year, however, President Chavez's new Constitution abolished the Judicial Council (Consejo de la Judicatura) responsible for recruiting, training, and disciplining judges, as well as the newly independent Supreme Court, replacing them with a Supreme Tribunal of Justice combining both functions.' loyalists.

Significant legal change can be effectuated, but it must be done without insulting or revolutionizing the local legal culture. For example, Henry II of England created an entirely new King's Court, consisting of independent judges who followed him around (i.e. "riding circuit"); and he adopted the jury trial. As the public realized that his judges were not partisan like local courts and were better prepared than local lords to adjudicate disputes fairly, his court became ever more popular. Similarly, the jury trial was a significant improvement on trial by ordeal. Thus, the common law eventually won out over the competition because it presented a better product.

Similarly, while Venezuela's new judicial system was failing, Chile rebuilt its entire criminal justice system (followed by labor and family courts), using its own money ( $\$ 500$ million) to do so. As with Henry II's court, Chile's new system was an improved product and beat the pre-existing competitor. Prior to 1997, Chile used the inquisitorial system it had inherited from colonial Spain. Each criminal trial was conducted by a single judge responsible for the entire trial. There were no prosecutors and defense counsel had little power to intervene. The trial consisted of a secret pre-trial phase to determine if a crime had been committed, and a public phase where the judge disclosed the evidence, decided guilt or innocence, and sentenced the defendant.

Chileans reached a public and political consensus recognizing a number of problems with the system, including biased judges, ineffective investigation, substantial delays, lack of transparency, lack of rights protection for the accused, and the concentration of power. The 1997 Congress adopted an amendment making substantial changes. While U.S. advisors were used in 
the development of the new system, and it borrowed ideas from the U.S., the system adopted was uniquely adapted to Chile by Chileños.

The real genius of the Chilean reforms was in the thoughtful way they were both developed and implemented. The proposed changes were developed in a way designed ultimately to blend in with the existing culture; however, rather than mandate that established judicial personnel learn new systems, young, ambitious law students were recruited and trained in the various roles (often by Spanish-speaking U.S. instructors). These future prosecutors, defense counsel, victim representatives, judges, and court clerks then gained preliminary experience through simulated trials. At this point, Chile implemented pilot programs in two regions to test-run the new adversarial system, applying it prospectively only. Chile also recognized that the general public needed to know, understand, and accept the reforms, including the new presumption of innocence, the right to a defense, and how the new trials worked. Consequently, the Chilean government's publicity campaign included a film on comparative justice and an animated series, Superheroes Legales, about lawyers who "transform into superheroes defending the innocent, providing access to justice, and building the rule of law." After the pilot, a secondary system of courts was created, and gradually phased in. The new system significantly improved transparency, speed, due process, impartiality, and professionalism.

Thus, legal change is most effective if a consensus is reached that change is necessary, and on what changes need to be made; and if those changes are then implemented in a gradual manner, using the benefit of competition, rather than ignoring local culture and simply trying to force change upon those who have already established habits and expectations.

It is hoped that this book will allow creative minds to view these and other legal problems in a new way, as well as find effective ways to implement positive change.

\section{NOTES}

1. Michael Oakeshott, "The Rule of Law" in On History and Other Essays 178 (1986).

2. Roger Scruton, "Brexit: Yes or No?," YouTube (November 26, 2015), www .youtube.com/watch?V=Bvlg8YK3iSU.

3. Lord Ashcroft, "How the United Kingdom Voted on Thursday ... And Why," lordashcroftpolls.com (June 24, 2016), http://lordashcroftpolls.com/2016/06/how -the-united-kingdom-voted-and-why/.

4. See "2017 Economic Freedom of the World Heat Map," Heritage Fund, www .heritage.org/index/heatmap; World Justice Project, World Justice Project Rule of Law Index 2016, at 5 (2016), https://worldjusticeproject.org/sites/default/files/ documents/roli_Final-Digital_0.pdf.

5. See Martin Lee, "Opinion: This May Be China's Worse Assault Yet on the Rule of Law in Hong Kong," Washington Post (May 15, 2019), www.washingtonpost 
.com/opinions/2019/05/15/this-may-be-chinas-worst-assault-yet-rule-law-hong -kong/ (on extradition); Tom McCarthy, "Under the Umbrellas: What do Hong Kong Protesters Want from China," The Guardian (September 29, 2014), www.theguardian.com/world/2014/sep/29/hong-kong-democracy-protests-china -umbrellas-police.

6. See generally, Nadia E. Nedzel and Nicholas Capaldi, The Anglo-American Conception of the Rule of Law (Palgrave Macmillan 2019). See also Friedrich Hayek, "Sociology: Comte and his Successors," in 13 Studies on the Abuse and Decline of Reason 270-271 (ed. Bruce Caldwell, 2010) (discussing the effectiveness of inductive historical approach as opposed to the ineffectiveness of attempts at objective, scientistic approach as per sociology of knowledge).

7. Friedrich Hayek, "The Fatal Conceit: The Errors of Socialism," in The Collected Works of F.A. Hayek (University Chicago Press 1988).

8. Bruno Leoni, Freedom and the Law 61-68 (citing Dicey and Hayek) (Liberty Fund 3d ed. 1991).

9. Stephen M. Bainbridge, The New Corporate Governance in Theory and Practice (Oxford University Press 2008).

10. See Cass Sunstein, "Paradoxes of the Regulatory State," in Morality \& the Market: Ethics \& Virtue in the Conduct of Business (Eugene Heath, ed. 2002), excerpted from Cass Sunstein, Free Markets and Social Justice (1997) (arguing that in the regulatory state, legislation sometimes achieves ends that are precisely opposite to those intended).

11. Michael Oakeshott, On Human Conduct 111-13 (discussing "civil association"), 114-16 (discussing "enterprise association") (Clarendon Press 1990).

12. Rainer Grote, "Chapter 13: The German Rechtsstaat in a Comparative Perspective," 38 IUS Gentium 193, 199-200 (2014).

13. Lon. L. Fuller, The Morality of Law 210 (Yale University Press 1969).

14. Nadia E. Nedzel, "The International Rule of Law and Economic Development," 17 Wash. U. Global Stud. L. Rev. 447, 454 (2018).

15. See Frank B. Cross, "The Error of Positive Rights," 48 UCLA L. REV. 857, 858-62 (2002) (describing positive rights as (ineffective) rights to health, housing, clothing, and so on as contrasting with the negative rights provided in the United States Constitution, which show a pragmatic understanding of the operation of government). See also John Hasnas, "From Cannibalism to Caesareans: Two Conceptions of Fundamental Rights," 89 NW. U. L. REV. 900, 901 (1995) (describing classical (i.e. negative) rights as "indefeasible, morally fundamental entities that protect individual autonomy," and contrasting them with contemporary (i.e. positive) rights as means to the achievement of more fundamental moral interests); and John Hasnas, "The Myth of the Rule of Law," 1995 WIS. L. REV. 199 (1995).

16. See Charles Howard McIlwain, The High Court of Parliament and its Supremacy: An Historical Essay on the Boundaries between Legislation and Adjudication in England 44 (Yale University Press 1910).

17. Arzu Oguz, "The Role of Comparative Law in the Development of Turkish Civil Law," 17 Pace Int'l L. Rev. 373, 381-85 (2005) (discussing problems that came with the shift to the Swiss Civil Code). These problems were apparently dealt with by allowing a loose translation. Ruth A. Miller, "The Ottoman and Islamic Substratum of Turkey's Swiss Civil Code," 11 J. Islamic Stud. 335, 335-61 (2000) (stating that the subsequent loose translation allowed for a better fit between the code and the society to which it was applied). See also Konrad Zweigert and Hein 
Kötz, Introduction to Comparative Law 184-85 (Tony Weir trans., Clarendon Press 3d ed. 1998).

18. Institute of Latin Am. Studies, Rule of Law in Latin America: The International Promotion of Judicial Reform 18-20 (Pilar Domingo and Rachel Sieder eds., 2001).

19. See Nadia E. Nedzel, "The Rule of Law: Its History and Meaning in Common Law, Civil Law, and Latin American Judicial Systems," 10 Rich J. Global L. \& Bus. 90-93 (2010) (and citations therein). This was the first article the author wrote on this topic. Her views have developed since then.

20. Peter Deshazo and Juan Enrique Vargas, Judicial Reform in Latin America: An Assessment, XVII Center for Strategic and International Studies Policy Papers on the Americas, Study 2, 10 (2006), http:// csis.org/files/media/csis/pubs/0609_latin judicial_reform.pdf.

21. Jorge Correa Sutil, Seminario en Latinoamérica de Teoría Constitucional y Politica: Access to Justice and Judicial Reforms in Latin America, Any Hope of Equality? 7 (1999). 